\title{
FOREWORD: GLOBAL AND REGIONAL PERSPECTIVES ON INTERNATIONAL HUMANITARIAN LAW
}

\author{
Alberto Costi*
}

It is a great privilege to write the foreword to this special issue bringing together a number of global and regional perspectives on international humanitarian law (IHL) in commemoration of some of the most significant events marking the emergence and development of what is still a relatively recent yet dynamic branch of international law. The Law Review takes this opportunity to express its gratitude to the New Zealand Red Cross and to the International Committee of the Red Cross Regional Delegation in the Pacific for their generous support, which has enabled the publication of this special issue.

In the past year, the international community remembered the 150th anniversary of the Battle of Solferino, ${ }^{1}$ marked the 145 th anniversary of the first Geneva Convention for the Amelioration of the Condition of the Wounded in Armies in the Field ${ }^{2}$ and celebrated the 60th anniversary of the 1949 Geneva Conventions. ${ }^{3}$ The Geneva Conventions all originate from an idea formulated by Henry Dunant after he experienced first-hand the absence of any systematic effort by the armies fighting at Solferino to care for the wounded, leading him and others to create the "International Committee for Relief to the Wounded" in 1863, renamed International Committee of the Red Cross (ICRC) in

* Associate Professor, Faculty of Law, Victoria University of Wellington. I would like to thank the two student editors, Anne O'Driscoll and Chris Murray, as well as Denise Blackett, for their invaluable contribution in the preparation of this special issue.

1 For a frank account of the battle between Napoleon III's troops (supported by the Sardinians) and the Austrians, see JH Dunant Un Souvenir de Solférino (Imprimerie Jules-Guillaume Fick, Geneva, 1862).

2 Convention for the Amelioration of the Condition of the Wounded in Armies in the Field (adopted 22 August 1864, entered into force 22 June 1865) reprinted in D Schindler and J Toman (eds) The Laws of Armed Conflicts. A Collection of Conventions, Resolutions and Other Documents (4th ed, Martinus Nijhoff Publishers, Leiden, 2004) 365.

3 Convention (I) for the Amelioration of the Condition of the Wounded and Sick in Armed Forces in the Field, Convention (II) for the Amelioration of the Condition of Wounded, Sick and Shipwrecked Members of Armed Forces at Sea, Convention (III) relative to the Treatment of Prisoners of War and Convention (IV) relative to the Protection of Civilian Persons in Time of War (opened for signature 12 August 1949, entered into force 21 October 1950). 
1876. Established as a Swiss non-governmental permanent organisation, the ICRC would become the catalyst for improved medical services in wartime and the adoption of the first international conventions dealing with the wounded. ${ }^{4}$ Dunant's proposal was based on three novel propositions: the ability of the law "to limit and control violence"; the treatment of enemy combatants who fell into one's hands "according to the same principles as one's own military personnel"; and, a clear focus on the victims of armed conflict. ${ }^{5}$ Despite possible infringement on State sovereignty and limitations to military strategy, the first Geneva Convention was adopted by 16 States at the Diplomatic Conference convened by the Swiss government in Geneva in August $1864 .{ }^{6}$ It laid the foundation for the first codification and later development of one of the two main arms of the contemporary law of armed conflict, the so-called Geneva law. ${ }^{7}$

Yet, one could be forgiven for passing on the opportunity to celebrate such a momentous event. Even the occasional follower of current affairs glancing at the recent past may wonder whether the reality has caught up with the discourse and rhetoric of the international community. The first half of the 1990s saw some of the worst atrocities committed since World War II occurring on the doorstep of Western Europe in the former Yugoslavia, especially in Bosnia and Herzegovina. A few years later, a coalition of member States of the North Atlantic Treaty Organization embarked on a 78-day bombing campaign to force the then Yugoslav government to end the alleged repression of

4 See C Greenwood "Historical Development and Legal Basis" in D Fleck (ed) The Handbook of International Humanitarian Law (2nd ed, Oxford University Press, Oxford, 2008) 1 at 22. Dunant's ideals might never have become a reality if not for the pragmatic approach of his compatriot Gustave Moynier, who ensured that their realisation would not be left to States, but would be realised through the presence of civilians onto the battlefield, organised in national committees to help the State's army medical personnel, starting with the establishment of the Committee of Five (with General Guillaume-Henri Dufour, Dr Louis Appia and Dr Théodore Maunoir), turning into a permanent committee in 1863, renamed International Committee of the Red Cross (ICRC) in 1876: see V Harouel-Bureloup Traité de droit humanitaire (Presses universitaires de France, Paris, 2005) at 105-106.

5 D Thürer "International Humanitarian Law: Essence and Perspectives" [2007] RSDIE 1 at 1-2.

6 See SM Cohen Arms and Judgment. Law, Morality, and the Conduct of War in the Twentieth Century (Westview Press, Boulder, 1989) at 3, who writes that the 1864 Convention was opposed by the military and by ministers, but supported by "all the crowned heads of the Continent" who had read Dunant's account of the Battle of Solferino.

7 F Bugnion "The International Committee of the Red Cross and the Development of International Humanitarian Law" (2004) 5 Chi J Int'l L 191 at 193. The law of armed conflict has two principal arms, traditionally referred to as Geneva and Hague law. The Geneva law or international humanitarian law (IHL) derives from the Geneva Conventions and Conferences and focuses on the protection of the victims of armed conflict. The other arm of the law of armed conflict, the Hague law, was partially codified in 1899 and 1907 at The Hague Peace Conferences in conventions and regulations which govern the rights and obligations of belligerents. It focuses on methods and means of warfare, tactics and the general conduct of hostilities: see Lt-Comm GP Noone "The History and Evolution of the Law of War Prior to World War II" (2000) 47 Naval L Rev 176 at 177-178. 
the predominantly ethnic Albanian population of the province of Kosovo. ${ }^{8}$ Beyond the European continent, from April to mid-July 1994, almost one million people in Rwanda perished as the result of a genocide taking place against the background of a civil war, with the international community tangled in a web of political concerns and self-interests. ${ }^{9}$ The Sudan also saw its fair share of suffering, with the civil war erupting along primarily religious lines between Khartoum and the South, and more recently in the Darfur region, with a heavy account of casualties ${ }^{10}$ amid claims of genocidal conduct. ${ }^{11}$ The 20th century witnessed two global wars, countless humanitarian crises and the trend in the new millennium runs unabated, with conflicts in Afghanistan and Iraq still in the limelight.

This special issue devoted to IHL assembles articles from contributors from Australia, New Zealand, the United Kingdom and the United States of America who reflect on various aspects of a body of law in constant evolution, as echoed by the recent entry into force of the Clusters Munitions Convention. ${ }^{12}$ Recognising the significant achievements of IHL, the contributors to this issue also acknowledge the challenges associated to its implementation and point to some of the issues lying ahead. For instance, the introductory remarks of the New Zealand Red Cross ${ }^{13}$ stress the basic principles underlying the Geneva Conventions: the notion of respect for the life and dignity of the individual and the duty for all parties to a conflict to ensure that those who suffer in conflict be aided and cared for without distinction. Noble as they may be, these principles continue to be tested in contemporary conflicts of an international or non-international character. For example, the protection of health workers and the actual delivery of health care to the victims of armed conflicts remain a priority for the ICRC and national Red Cross and Red Crescent societies, but the support

8 The ethnic cleansing campaign and the flux of refugees who poured into Macedonia before and after the North Atlantic Treaty Organization's campaign saw the displacement of over half a million people within and beyond Kosovo's borders. See generally M Barutciski "Peut-on justifier l'intervention de l'OTAN au Kosovo sur le plan humanitaire? Analyse de la politique occidentale et ses conséquences en Macédoine" (2000) 38 Can Yb Int'l L 121. For an account of the bombing campaign in Kosovo, see WJ Fenrick "Targeting and Proportionality during the NATO Bombing Campaign against Yugoslavia" (2001) 12 EJIL 489.

$9 \quad$ "The Road out of hell" The Economist (27 March 2004) at 25.

10 The United Nations estimates that seven years of war between military forces and rebel groups have killed some 300,000 people and driven almost three million more from their homes in Darfur: "UN relief chief sounds alarm on Darfur's dire humanitarian situation" (29 May 2010) UN News Centre <www.un.org>.

11 M Kelemen "Bush Pressures Sudan Over Darfur Genocide" (29 May 2007) National Public Radio $<$ www.npr.org $>$.

12 Convention on Cluster Munitions (opened for signature 3 December 2008, entered into force 1 August 2010)

13 New Zealand Red Cross "The Red Cross and the Geneva Conventions - 60 Years On" (2010) 41 VUWLR 113. 
and commitment of governments, armed forces and non-State armed groups required for their success are not always forthcoming.

The first two substantive articles examine the values embodied in the Geneva Conventions and the universal coverage they have now achieved, as well as the impact of humane values on the conduct of armed conflict more generally. Sir Kenneth Keith, Judge at the International Court of Justice,${ }^{14}$ offers a historical overview of the development of the ICRC as both a movement and institution and highlights the fundamental and universal values underpinning IHL. These include the principles of humanity, non-discrimination in the treatment of all wounded combatants and protection of those engaged in bringing help to the wounded and sick. Such principles are found in treaties, military manuals and other practices, such as that of a Maori warrior in the midst of the land wars in New Zealand in the 1860s, roughly at the same time as, on the other side of the planet, the Lieber Code was enacted to govern the activities of the Union Army during the American Civil War. ${ }^{15}$ Sir Kenneth Keith concedes that ratification of the Geneva Conventions is only a first step; implementation necessitates both the active involvement of the international community and the commitment of national authorities. Kelisiana Thynne, Legal Adviser at the International Committee of the Red Cross Regional Delegation in the Pacific, ${ }^{16}$ examines the relevance of IHL for the Pacific. On the one hand, all States in the region have now ratified the Geneva Conventions and most are or are considering becoming parties to the Rome Statute of the International Criminal Court ${ }^{17}$ and to the Convention on the Prohibition of Anti-Personnel Mines. ${ }^{18}$ The importance of IHL for Pacific islands may appear questionable in view of their limited capacity and resources and more pressing issues requiring the attention of their governments. Nevertheless, she stresses its pertinence for a region remaining vulnerable to internal conflict due to tensions related to land disputes and emerging issues such as climate change. Because many international operations depend on military contingents comprising soldiers from the region, it is crucial that the Geneva Conventions and other IHL instruments figure prominently in the training programmes of armed forces called upon to carry out field operations. Interestingly, these two first contributions enable us to view IHL not only as embodying a set of values common to all nations on Earth, but also as a legal language transcending borders. IHL protects both civilians and combatants in the midst of an

14 KJ Keith "Tutti Fratelli? Perspectives and Challenges for International Humanitarian Law" (2010) 41 VUWLR 123.

15 Instructions for the Government of Armies of the United States in the Field, General Orders No 100 (Lieber Code) (24 April 1863) reproduced in Schindler and Toman, above n 2, 3.

16 Kelisiana Thynne "The Universality of IHL - Surmounting the Last Bastion of the Pacific" (2010) 41 VUWLR 135.

17 Rome Statute of the International Criminal Court (opened for signature 17 July 1998, entered into force 1 July 2002).

18 Convention on the Prohibition of the Use, Stockpiling, Production and Transfer of Anti-Personnel Mines and on their Destruction (opened for signature 18 September 1997, entered into force 1 March 1999). 
armed conflict. This suggests that the advent of IHL is somehow a natural humane response to an evident need, growing out of recognition by both individuals and society in general that, especially in wars, there is an imperative duty to protect and preserve those who cannot protect themselves or who need special attention. The coverage of the Geneva Conventions is thus universal albeit not perfect and sometimes subject to protagonists in conflict testing its boundaries.

The common theme in the subsequent three papers resides in the enforcement of IHL. Brigadier KJ Riordan ${ }^{19}$ provides a case study of the Sarajevo siege within the wider discussion of the relevant Hague and Geneva law relating to shelling, starvation and sniping. There is a fine line between what is permitted and what is not during an armed conflict. While many of the principles were codified in the Hague law at the turn of the 20th century and refined in the 1977 Additional Protocol I to the Geneva Conventions, ${ }^{20}$ in the heat of a battle, the applicability of legal instruments regarding the choice of strategy and methods of warfare gives rise to tough challenges. Not only does he provide an exhaustive tour d'horizon of the relevant legal provisions, but he does so by discussing and reviewing the case law of the International Criminal Tribunal for the former Yugoslavia, in particular the prosecution cases relating to the siege of Sarajevo. He points out that the convictions and the heavy sentences they carry must provide a cautionary tale for commanders who may be required to undertake such operations in future. Continuing on the theme of IHL enforcement, Professor Steven Freeland ${ }^{21}$ examines the controversial issue of prosecution of Heads of State. He offers some thoughts and reflections on the political, legal and historical dimensions that have combined to allow for the prosecution under international criminal law of any person, irrespective of their official capacity. His review of the practice of international and internationalised tribunals, especially the explicit rejection in their statutes of the immunity of Heads of State from prosecution for violations of IHL, and his reference to the fact that domestic courts in some countries have also grappled with the concept herald the end of impunity. Dr Richard Burchill ${ }^{22}$ argues that regional arrangements can strengthen the enforcement of IHL by filling the gap arising from the limitations of universal approaches such as that offered by the International Criminal Court and the inability or unwillingness of States to enforce IHL at the domestic level. Rather than viewing them as deviant from the universal system, he believes regional arrangements should be seen as contributing to the universal aspirations of international law while at the same time supporting expressions of diversity. In his view, greater attention to regional arrangements will help to effectively foster a stronger

19 KJ Riordan "Shelling, Sniping and Starvation: The Law of Armed Conflict and the Lessons of the Siege of Sarajevo" (2010) 41 VUWLR 149.

20 Protocol Additional to the Geneva Conventions of 12 August 1949, and relating to the Protection of Victims of International Armed Conflicts (Protocol I) (opened for signature 8 June 1977, entered into force 7 December 1978).

21 Steven Freeland "A Prosecution too far? Reflections on the Accountability of Heads of State under International Criminal Law" (2010) 41 VUWLR 179.

22 Richard Burchill "Regional Approaches to International Humanitarian Law" (2010) 41 VUWLR 205. 
global approach to international law, respectful of cultural and regional differences. Needless to say, a more effective enforcement of existing legal provisions shall facilitate the task of the ICRC in the dissemination of IHL.

The last two articles draw our attention to more peripheral considerations on IHL. Professor Richard Boast ${ }^{23}$ takes us back in time. He offers an exhaustive insight into the scholarly debate regarding the role of Francisco de Vítoria and Bartolomé de Las Casas in the development of international law, human rights law and indigenous rights, and more generally on the influence of Spanish metropolitan views on what was actually happening in the New World in colonial times. This article shows that humanitarian concepts predated the development of legal norms and gave impetus to the emergence of specialised areas of law. Lastly Professors Michael Kelly and Sean Watts $^{24}$ jointly examine the role of collective security arrangements in reducing the risk of conflict and ensuring regional stability. They ponder whether it is time for the formation of a collective security structure in North East Asia in view of some long-standing disputes, unresolved differences and simmering tensions in that region, and wonder whether the pursuit of long-term stability could drive China, Russia and the United States into a workable arrangement. Looking into the future, they believe that despite the challenges of bringing together non-allies, advantages would include reliance, predictability, mutually agreed obligations and, arguably, the stability and durability of the security agreement. In turn, a regional security organisation would ensure respect among the State parties for the rules on the resort to armed attack and the lawful conduct of hostilities.

What would Henry Dunant make of the current body of IHL if he were still alive in 2010? He would be aggrieved to learn that the 20th century was marred by two global conflicts and numerous other international and non-international armed conflicts killing and displacing millions of people, and frustrated by the gap between acceptance of the rules on paper and their implementation in the field continuing in the nouveau millénaire. However, he would be pleased to know that humanitarian principles in times of war have crystallised into a universally accepted body of rules increasingly enforced by international and internationalised tribunals as well as domestic courts. He would also relish in the knowledge that former and current Heads of State may now be prosecuted for the consequences of their actions. Most of all, he would hold some hope that our generation has taken to heart the combat against impunity. Although we continue to witness war, the International Committee of the Red Cross, which has generated a Movement that spans the globe 150 years after Solferino, continues to play a vital role in protecting all those afflicted by conflict, in a humane and indiscriminate fashion. After all, siamo tutti fratelli!

23 Richard Boast "The 'Spanish' Origins of International Human Rights Law: A Historiographical Review" (2010) 41 VUWLR 235.

24 Michael J Kelly and Sean Watts "Rethinking the Security Architecture of North East Asia" (2010) 41 VUWLR 273. 